\title{
Unsustainability of recommended fertilization rates for coffee monoculture due to high $\mathrm{N}_{2} \mathrm{O}$ emissions
}

\author{
Daniel Capa $^{1}$ (D) Javier Pérez-Esteban ${ }^{2}$ - Alberto Masaguer ${ }^{2}$
}

Accepted: 22 May 2015 / Published online: 11 June 2015

(C) INRA and Springer-Verlag France 2015

\begin{abstract}
Industrial fertilization with an excess of mineral fertilizer leads to water pollution and global warming. For instance, high mineral fertilization rates in coffee plantations of Ecuador result in $\mathrm{N}$ losses, such as emissions of $\mathrm{N}_{2} \mathrm{O}$, a greenhouse gas to the atmosphere. Therefore, we conducted here field experiments to optimize fertilization. We studied the effects of mineral fertilizers on soil fertility, $\mathrm{N}_{2} \mathrm{O}$ emissions, productivity, and profitability of monoculture coffee systems in Loja, Ecuador. During 2 years, treatments on plots of Coffea arabica included (1) low fertilization with $70 \mathrm{~N}, 22 \mathrm{P}$, and $31 \mathrm{~K} \mathrm{~kg} / \mathrm{ha} /$ year first year and then $200 \mathrm{~N}, 65 \mathrm{P}$, and $62 \mathrm{~K}$ second year; (2) medium fertilization with $150 \mathrm{~N}, 44 \mathrm{P}$, and $62 \mathrm{~K}$ first year and then $300 \mathrm{~N}, 87 \mathrm{P}$, and $125 \mathrm{~K}$ second year; (3) high fertilization with $225 \mathrm{~N}, 65 \mathrm{P}$, and $93 \mathrm{~K}$ and then 400 N, 109 P, and $187 \mathrm{~K}$ second year; and (4) control plots without fertilizers. Results showed that, although medium-high fertilization rates recommended by experts gave high coffee yields and income, such treatments produced high $\mathrm{N}_{2} \mathrm{O}$ emissions and thus led to low production $/ \mathrm{N}_{2} \mathrm{O}$ emissions ratios of 208 for medium fertilization, and of 188 for high fertilization. Low fertilization gave a high production $/ \mathrm{N}_{2} \mathrm{O}$ ratio of 603 , and an income of $7606 \mathrm{USD} / \mathrm{h}$ h higher than control, of $3524 \mathrm{USD} / \mathrm{ha}$. Our findings demonstrate that rates based on expert recommendations from local extension services and usually applied
\end{abstract}

Daniel Capa

edcapa@utpl.edu.ec

1 Department of Agricultural Sciences, Vegetable Production, Universidad Técnica Particular de Loja, San Cayetano Alto s/n, 1101608 Loja, Ecuador

2 Department of Soil Science, Agricultural Engineering School, Universidad Politécnica de Madrid, Avenida Complutense s/n, 28040 Madrid, Spain by Ecuadorian coffee growers, such as our medium rate, fail to achieve a sustainable production. The application of approximately half the expert recommended rates, such as our low treatment, could allow an environmental and economic sustainability in monoculture coffee plantations of Ecuador.

Keywords Mineral fertilization - Nitrous oxide emissions . Coffea arabica $\cdot$ Monoculture coffee $\cdot$ Sustainable agriculture $\cdot$ Ecuador

\section{Introduction}

Coffee is the most intensively traded tropical agricultural commodity worldwide, cultivated in over 50 countries and covering more than 11 million ha (De Beenhouwer et al. 2015). In Ecuador, coffee production has a great social, economic, and ecological importance because more than $4 \%$ of the population directly relies on coffee production for their livelihoods; it is a primary source of foreign exchange for private producers and the State and it is part of the diverse agrosystems of the country. However, its yield is deficient $\left(196 \mathrm{~kg} \mathrm{ha}^{-1}\right)$ in comparison with the production of Brazil and Colombia, whose yields are greater than $1897 \mathrm{~kg} \mathrm{ha}^{-1}$ (COFENAC 2011). This low yield of coffee production in Ecuador is due to lack of crop mechanization and irrigation systems, scarce renewal of aging plantations, limited post-harvest management, and unawareness of soil characteristics and of appropriate fertilization programs by coffee producers (COFENAC 2011; FAO 2002). In these coffee systems, fertilization is not well matched because of lack of information by producers, which is reflected in a low productivity and profitability.

The increasing number of monoculture coffee systems in Latin America during the last years has resulted in high application of mineral fertilizers to improve the productivity and 
profitability of those plantations (Romero-Alvarado et al. 2002). However, the excessive use of these inputs by coffee growers results in environmental problems. Borbor-Cordova et al. (2006) reported a great accumulation of $\mathrm{N}$ and $\mathrm{P}$ in the Guayas River basin of Ecuador in which synthetic fertilizers were the largest input for N (53\%) and P (57\%). About $14 \%$ of $\mathrm{N}$ and $38 \%$ of $\mathrm{P}$ inputs were leached to rivers, which leads to water quality problems, such as eutrophication. As well, De Beenhouwer et al. (2015) reported a strong reduction of soil microorganism diversity in intensively managed coffee systems, where chemical fertilizers and pesticides are abundantly used.

Agriculture not only is the main source of water and soil contamination by nitrates, phosphates, and pesticides but also severely affects climate change, as it is the major contributor to the emissions of greenhouse gases (FAO 2002), especially of nitrous oxide $\left(\mathrm{N}_{2} \mathrm{O}\right)$ due to $\mathrm{N}$ fertilization (Hergoualc'h et al. 2008; Mosier et al. 1996). This compound not only destroys the ozone layer but is also a long-lived greenhouse gas responsible for $5 \%$ of global warming, which could contribute as much as $10 \%$ in the future (Mosier et al. 1996; Rochette et al. 2004). Coffee agriculture represents $7.5 \%$ of worldwide perennial crop production with typical fertilization rates ranging from 150 to $350 \mathrm{~kg} \mathrm{~N} \mathrm{ha}^{-1}$ per year in intensively managed systems; hence, it could contribute to considerable $\mathrm{N}_{2} \mathrm{O}$ emissions in the future (Hergoualc'h et al. 2008). Latin American coffee production has made a major contribution to greenhouse gas emissions from land use change in the recent past, with 1.1 million ha converted from agroforests to lightly shaded or full sun coffee systems by the mid-1990s in Mexico, Central America, Colombia, and the Caribbean (van Rikxoort et al. 2014). Borbor-Cordova et al. (2006) estimated in their study in Ecuador about $25 \%$ losses of applied $\mathrm{N}$ fertilizer by denitrification, which allows $\mathrm{N}_{2} \mathrm{O}$ production, and about $20 \%$ by ammonia volatilization.

In order to attain a sustainable coffee production, the application of agricultural practices must consider several aspects: appropriate environmental management that minimizes the environmental problems mentioned above, profitable production, and prosperity of rural communities, aspects that should satisfy the needs of producers and society. Coffee growers of Ecuador generally overuse fertilizers because of the common belief that an excess results in higher production and profit without the consideration of consequent environmental problems. Castro-Tanzi et al. (2012) studied the effects of the application of mineral fertilizers in several coffee plantations in Latin America, showing a positive relationship between nutrient application rates and yields. However, these authors also reported that the constant use of fertilizers by producers led to changes in soil chemistry, such as acidification or depletion of other nutrients, and that in most cases, $\mathrm{N}$ inputs exceeded crop requirements, which could result in $\mathrm{N}$ losses as $\mathrm{N}_{2} \mathrm{O}$ emissions and $\mathrm{NO}_{3}{ }^{-}$leaching. Van Rikxoort et al. (2014) compared the carbon footprint in different coffee production systems of Latin America, reporting the highest values in monoculture systems, where coffee is produced with regular applications of synthetic fertilizers and pesticides. These authors estimated that in those intensively managed systems, about $30 \%$ of the carbon footprint was due to fertilizer production and application including background soil emissions.

Many studies have investigated the influence of fertilization on yields and greenhouse gas emissions in intensive and conventional agricultural systems. However, there is little information about the use of mineral fertilizers on monoculture coffee systems, particularly in Ecuador, considering not only the economic viability but also the environmental viability, in which other costs such as $\mathrm{N}_{2} \mathrm{O}$ emissions are taken into account.

The aim of this work was to evaluate the effects of three different rates of mineral NPK fertilizers on nutrient contents and other chemical properties of soils, nitrous oxide emissions to the environment, and productivity and profitability of coffee plantations in the Loja region in Ecuador (Fig. 1). The intermediate fertilization rate used in this study was based on Iñiguez (1996) recommendations for intensively managed coffee systems, typically applied in Ecuador. This highly fertilized treatment was compared with higher and lower rates, and all of them were critically analyzed for economic and environmental viability. Thus, this study provides information about the optimal fertilization rates that should be applied by coffee growers in order to achieve a more sustainable production.

\section{Materials and methods}

\subsection{Study area}

The study area $\left(3^{\circ} 58^{\prime} 35^{\prime \prime} \mathrm{S}, 79^{\circ} 12^{\prime} 15^{\prime \prime} \mathrm{W}, 2100 \mathrm{~m}\right.$ above sea level; GEO Loja 2007) was located in the Loja region (Ecuador), where there is an important coffee production activity of the country. The climate of this area is humid temperate with a mean annual rainfall of $910 \mathrm{~mm}(1125 \mathrm{~mm}$ in 2011, $808 \mathrm{~mm}$ in 2012; Weather Station of Particular Technical University of Loja, $4^{\circ} 00^{\prime} \mathrm{S}, 79^{\circ} 12^{\prime} \mathrm{W}$ ), which has its seasonal maximum between January and April as well as other lower maximum in October, and a mean annual temperature of $18{ }^{\circ} \mathrm{C}$ (Sierra 1999). Soils have been classified as Inceptisols (GEO Loja 2007). As shown in Table 1 (initial soil properties in 2011), soils were clay loam and slightly acidic, which were within an appropriate range for coffee production $(\mathrm{pH} 5.5-6.5)$. The organic matter (2-5\%) and $\mathrm{K}$ contents $\left(78-274 \mathrm{mg} \mathrm{kg}^{-1}\right)$ also exhibited optimal levels, whereas total $\mathrm{N}(<3 \%)$ and $\mathrm{P}$ $\left(<6 \mathrm{mg} \mathrm{kg}^{-1}\right)$ contents were low, according to PROCAFE (1995). The natural vegetation of this area corresponds to 
Fig. 1 a Second year (2012) of the field experiment with coffee plant Coffea arabica L. var. Caturra grown in a monoculture system at full sun exposure and $\mathbf{b}$ fertilization of coffee plants, applied by hand under the secondary branches

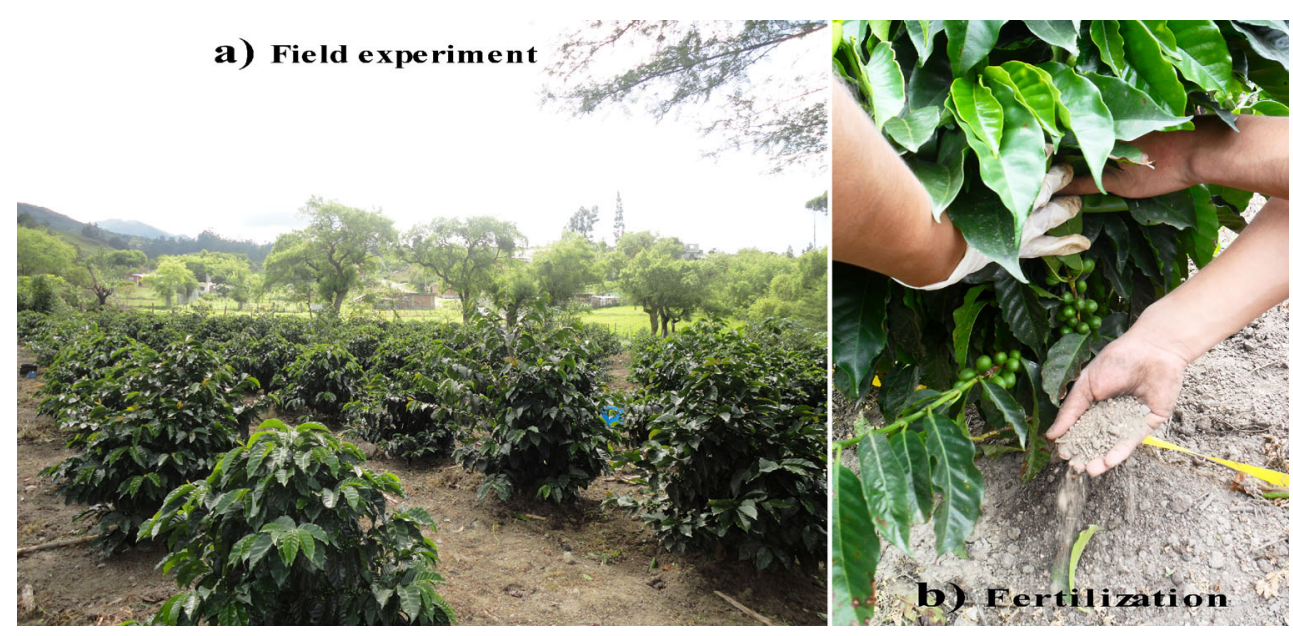

montane wet shrublands, which have been degraded and replaced with crops and eucalyptus forests (Sierra 1999).

\subsection{Field methods}

A field experiment was conducted using 1-year-old coffee plants, Coffea arabica L. var. Caturra (Fig. 1a), grown in a monoculture system at full sun exposure and with a planting distance of $2 \times 2 \mathrm{~m}$ and two plants per hole (5000 plants ha $\left.{ }^{-1}\right)$. An area of $2520 \mathrm{~m}^{2}$ was selected, where 12 plots of $10 \times 5 \mathrm{~m}$ were established. The experimental design consisted of split plots with three replications for each treatment. The crop was planted in January 2010, mineral fertilization started at January 2011, and the last harvest was done in June 2012.

Four different fertilization treatments were established, which consisted in the application of mineral $\mathrm{N}$ from urea (44\% total N; $44 \%$ organic N; Distribuidora de Químicos Industriales S.A., Medellín, Colombia), $\mathrm{P}$ from rock phosphate (FOSFORITA 28P; $28 \% \mathrm{P}_{2} \mathrm{O}_{5} ; 38 \% \mathrm{CaO} ; 14 \%$ $\mathrm{SiO}_{2} ; 3.3 \%$ solubility in $2 \%$ ammonium citrate; $100 \%<$ $0.83 \mathrm{~mm}, 40 \%<0.15 \mathrm{~mm}$; Fosfatos del Huila, Neiva, Colombia), and $\mathrm{K}$ from muriate of potash $\left(95 \% \mathrm{KCl} ; 60 \% \mathrm{~K}_{2} \mathrm{O}\right.$; Corporación Minera de Bolivia, Uyuni, Bolivia) at different doses. Fertilization rates $\left(\mathrm{kg} \mathrm{ha}^{-1}\right.$ year $\left.^{-1}\right)$ applied in each treatment were as follows: low fertilization, with 70,22 , and $31 \mathrm{~kg}$ of $\mathrm{N}, \mathrm{P}$, and $\mathrm{K}$, respectively $\left(14,4.4\right.$, and $6.2 \mathrm{~g} \mathrm{plant}^{-1}$ of $\mathrm{N}, \mathrm{P}$, and $\mathrm{K})$, during the first year, and 200,65 , and $62 \mathrm{~kg}$ of $\mathrm{N}, \mathrm{P}$, and $\mathrm{K}\left(40,13.1\right.$, and $12.5 \mathrm{~g} \mathrm{plant}^{-1}$ of $\mathrm{N}, \mathrm{P}$, and $\left.\mathrm{K}\right)$ during the second year; medium fertilization, with 150,44 , and $62 \mathrm{~kg} \mathrm{~N}$, $\mathrm{P}$, and $\mathrm{K}\left(30,8.7\right.$, and $12.5 \mathrm{~g} \mathrm{plant}^{-1}$ of $\mathrm{N}, \mathrm{P}$, and $\left.\mathrm{K}\right)$ during the first year and 300,87 , and $125 \mathrm{~kg} \mathrm{~N}, \mathrm{P}$, and $\mathrm{K}(60,17.4$, and 24.9 g plant $^{-1}$ of $\mathrm{N}, \mathrm{P}$, and $\mathrm{K}$ ) during the second year; high fertilization, with 225, 65, and $93 \mathrm{~kg} \mathrm{~N}$, P, and $\mathrm{K}(45,13.1$, and $18.7 \mathrm{~g} \mathrm{plant}^{-1}$ of $\mathrm{N}, \mathrm{P}$, and $\mathrm{K}$ ) during the first year and 400 , 109 , and $187 \mathrm{~kg} \mathrm{~N}, \mathrm{P}$, and $\mathrm{K}\left(80,21.8\right.$, and $37.4 \mathrm{~g} \mathrm{plant}^{-1}$ of $\mathrm{N}$, $\mathrm{P}$, and $\mathrm{K}$ ) during the second year; and a control treatment without fertilizers. The medium fertilization rate was

Table 1 Soil properties at the beginning and at the end of the field experiment with coffee in the different treatments (control, low, medium, and high fertilization rates)

\begin{tabular}{|c|c|c|c|c|c|c|c|c|}
\hline \multirow[t]{2}{*}{ Soil properties } & \multicolumn{4}{|c|}{ Beginning (January 2011) } & \multicolumn{4}{|c|}{ End (June 2012) } \\
\hline & Control & Low & Medium & High & Control & Low & Medium & High \\
\hline $\mathrm{pH}$ & $6.34 \mathrm{aA} \pm 0.02$ & $6.33 \mathrm{aB} \pm 0.01$ & $6.35 \mathrm{aB} \pm 0.02$ & $6.34 \mathrm{aB} \pm 0.01$ & $6.33 \mathrm{bA} \pm 0.01$ & $6.28 \mathrm{aA} \pm 0.01$ & $6.28 \mathrm{aA} \pm 0.01$ & $6.29 \mathrm{aA} \pm 0.01$ \\
\hline Organic matter $(\%)$ & $2.56 \mathrm{aA} \pm 0.01$ & $2.52 \mathrm{aA} \pm 0.02$ & $2.60 \mathrm{aA} \pm 0.12$ & $2.61 \mathrm{aA} \pm 0.14$ & $2.26 \mathrm{aA} \pm 0.14$ & $2.79 \mathrm{bA} \pm 0.17$ & $2.81 \mathrm{bB} \pm 0.07$ & $2.89 \mathrm{bB} \pm 0.03$ \\
\hline $\mathrm{N}(\%)$ & $0.06 \mathrm{aA} \pm 0.00$ & $0.07 \mathrm{aA} \pm 0.01$ & $0.06 \mathrm{aA} \pm 0.01$ & $0.07 \mathrm{aA} \pm 0.01$ & $0.06 \mathrm{aA} \pm 0.00$ & $0.11 \mathrm{bB} \pm 0.05$ & $0.12 \mathrm{bB} \pm 0.01$ & $0.14 \mathrm{cB} \pm 0.00$ \\
\hline $\mathrm{P}\left(\mathrm{mg} \mathrm{kg}^{-1}\right)$ & $0.63 \mathrm{aA} \pm 0.04$ & $0.65 \mathrm{aA} \pm 0.02$ & $0.67 \mathrm{aA} \pm 0.04$ & $0.67 \mathrm{aA} \pm 0.05$ & $0.71 \mathrm{aB} \pm 0.10$ & $1.01 \mathrm{bB} \pm 0.07$ & $1.05 \mathrm{bB} \pm 0.11$ & $1.07 \mathrm{bB} \pm 0.04$ \\
\hline $\mathrm{K}\left(\mathrm{mg} \mathrm{kg}^{-1}\right)$ & $394 \mathrm{aA} \pm 0.03$ & $390 \mathrm{aA} \pm 0.04$ & $378 \mathrm{aA} \pm 0.06$ & $371 \mathrm{aA} \pm 0.14$ & $394 \mathrm{aA} \pm 0.04$ & $488 \mathrm{bA} \pm 0.08$ & $531 \mathrm{bcB} \pm 0.04$ & $558 \mathrm{cB} \pm 0.05$ \\
\hline Clay (\%) & $29.5 \mathrm{a} \pm 2.3$ & $35.3 \mathrm{a} \pm 4.5$ & $31.9 \mathrm{a} \pm 4.4$ & $31.4 \mathrm{a} \pm 5.1$ & & & & \\
\hline Sand $(\%)$ & $40.7 \mathrm{a} \pm 3.1$ & $39.2 \mathrm{a} \pm 5.6$ & $38.1 \mathrm{a} \pm 6.1$ & $40.4 \mathrm{a} \pm 2.5$ & & & & \\
\hline Texture & Clay loam & Clay loam & Clay loam & Clay loam & & & & \\
\hline
\end{tabular}

Mean \pm standard deviation, $n=3$. Values followed by the same lowercase letter within the same period of the experiment are not significantly different among treatments $(P<0.05)$. Values followed by the same uppercase letter within the same treatment are not significantly different between the beginning and the end of the experiment $(P<0.05)$ 
selected from Iñiguez (1996) recommendations for the first 2 years of a coffee plantation.

Fertilizers were applied by hand two times a year (January and June) around plants and buried in the soil within the top $5 \mathrm{~cm}$ under the secondary branches (Fig. 1b), accordingly to crop needs and soil properties, as well as recommendations provided by Iñiguez (1996).

Weeds were manually controlled and disease and pest management was done using organic and copper-based pesticides. All the plots were identically watered by flood irrigation only when needed (in December 2011, April 2012, and June-December 2012), with approximately $30 \mathrm{~L}$ per plant per week (40-50\% water from irrigation in these dry months).

\subsection{Soil sampling and analytical methods}

Soil samples from each plot were collected and analyzed at the beginning (January 2011) and at the end of the experiment (June 2012), as well as after each fertilizer application. Each sample consisted of six subsamples collected under plant crowns within the top $20 \mathrm{~cm}$.

Soils samples were analyzed for $\mathrm{pH}(1: 2.5 w / w)$, oxidizable organic matter using a modified Walkley-Black procedure (Nelson and Sommers 1996), total N by Micro Kjeldahl digestion (Bremner and Mulvaney 1982), P by Bray-Kurtz method (Murphy and Riley 1962), K by Olsen method (Suarez 1996), and texture by the hydrometer method (Gee and Or 2002).

\subsection{Sampling and determination of $\mathrm{N}_{2} \mathrm{O}$ emissions from soil}

Nitrous oxide fluxes were determined during the field experiment using closed chambers (Rondón 2000). One PVC chamber $(23 \mathrm{~cm}$ diameter $\times 27 \mathrm{~cm}$ height), hermetically sealed using a lid equipped with a small port for gas sampling, was permanently installed on each plot and buried at $5-\mathrm{cm}$ depth under the secondary branches of a random coffee plant, close to the location where fertilizers were applied. These chambers were closed for $31 \mathrm{~min}$; gas samples were collected every $10 \min (1,11,21$, and 31$)$ using a plastic syringe with an adapted valve and immediately transferred into $20-\mathrm{mL}$ preevacuated septum-capped glass vials (Vacutainers, Beckton Dickinson, Franklin Lakes, New Jersey). Gas samples were analyzed by gas chromatography (Shimadzu GC-14 B) equipped with flame ionization detection (FID), electron capture detection (ECD), and autosampler (Loftfield et al. 1997). The concentrations of $\mathrm{N}_{2} \mathrm{O}$ were calculated by comparison of integrated peak areas of samples with three standard gases $\left(\mathrm{CO}_{2}, 703.8,1503.3\right.$, and $5019 \mathrm{ppm} ; \mathrm{N}_{2} \mathrm{O}, 501,1001$, and $3003 \mathrm{ppb} ; \mathrm{CH}_{4}, 2026,10,200$, and 20,000 ppb). Gas fluxes were determined by the difference between concentrations at the 31 st and the 1st minute, and $\mathrm{N}_{2} \mathrm{O}$ emission rates were calculated by linear interpolation using the four gas samples per chamber, where at least three linear points were required in order to validate flux measurements (Koehler et al. 2009).

\subsection{Economic analysis of coffee production}

An estimation of the coffee production was calculated every year after the harvests. Coffee cherries were collected when at least $90 \%$ of them were ripe and then were sun-dried to constant weight, which was recorded. The final production was expressed as $\mathrm{kg} \mathrm{ha}^{-1}$ per year of "green coffee," considering that the outturn ratio for cherry (entire fruit) to green coffee (unroasted and dried beans that were still encased inside the endocarp after the removal of exocarp and mesocarp or pulp) for arabica coffee is $5: 1$.

Net income of these coffee systems, used in this study as economic viability criterion, was estimated as the difference between gross income and costs of coffee production. Gross income was calculated from coffee sales at average prices in 2011 and 2012, accordingly to the International Coffee Organization (ICO 2014). Total costs were estimated from average costs of the plantation establishment and its management: fertilization, weed control, disease and pest control, pruning, harvest, etc. As environmental viability criterion, production to nitrous oxide emissions ratios were calculated from green coffee production in $\mathrm{kg} \mathrm{ha}^{-1}$ across 2011 and 2012 divided by total $\mathrm{N}_{2} \mathrm{O}$ emissions in $\mathrm{kg} \mathrm{ha}^{-1}$ during the whole experiment.

\subsection{Statistical analyses}

Statistical treatment of the experimental data was performed using SPSS 17.0 software (SPSS Inc., Chicago, IL). Means were compared through one-way ANOVA using Tukey's test $(P<0.05)$. Where only two means were compared, significant differences were calculated from Student's $t$ test $(P<0.05)$. Standard deviations were calculated to determine the variability of means between replicates. Relationships between different parameters were determined by Pearson's correlation coefficients $(r)$ using a two-tailed test.

\section{Results and discussion}

\subsection{Effects of fertilization on nutrient contents in soil}

Soil properties did not show significant differences among the treatments at the beginning of the experiment (Table 1).

Soil $\mathrm{pH}$ significantly decreased at the end of the 2-year field experiment in the three mineral fertilization treatments $(P<0.05)$. There were not significant differences among the low, medium, and high fertilization treatments, but they were significantly lower than the control treatment $(P<0.05)$, where the initial soil properties remained unchanged after the 
experiment. This slight acidification was probably due to the nitrification of ammonium-based nitrogen fertilizer (CastroTanzi et al. 2012; Sadeghian-Khalajabadi et al. 2006). We show that soil $\mathrm{pH}$ was significantly and negatively correlated with $\mathrm{N}$ content in soils $(r=-0.79, P<0.01, n=12)$.

The mineral fertilization also affected the soil organic matter content, which increased especially in the medium and high fertilization treatments after the experiment $(P<0.05)$. There were not significant differences among the mineral treatments, but all of them were significantly higher than the control treatment $(P<0.05)$. This increase in organic matter could be due to the higher plant growth achieved in the fertilization treatments, and therefore to the higher amount of biomass incorporated into soils. In the control treatment, where there was a low plant growth, the soil did not exhibit an increase in the organic matter content. We found a significant and positive correlation between organic matter content and coffee production $(r=0.82, P<0.01, n=12)$. These results agreed with those of Basavaraju and Gururaja Rao (2000), who reported that organic matter content increases in the medium term because of the accumulation of litter in soil from coffee plants.

The $\mathrm{N}$ content significantly increased with the mineral fertilization treatments during the experiment $(P<0.05)$, and it also kept similar values to the initial ones in the control treatment. The high fertilization treatment had significantly higher $\mathrm{N}$ content than the other treatments $(P<0.05)$. There were not significant differences between medium and high rates, but both treatments were significantly higher than the control $(P<0.05)$.

Although $\mathrm{N}$ content increased with the addition of mineral fertilizers, this increase was relatively low, probably due to the high extraction rate by plants during the first flowering and fruit development stages and the limited increase in organic matter. The content of $\mathrm{N}$ in soils was significantly and positively correlated with organic matter content $(r=0.91$, $P<0.01, n=12$ ). In addition, there may have been important $\mathrm{N}$ losses from soil due to plant uptake and the formation of gaseous inorganic nitrogen compounds emitted to the atmosphere (Borbor-Cordova et al. 2006; Hergoualc'h et al. 2008; Noponen et al. 2012). Moreover, a considerable amount of $\mathrm{N}$ could have been lost through nitrate leaching (Castro-Tanzi et al. 2012; Tully et al. 2012).

Concerning $\mathrm{P}$, its levels significantly increased in all the treatments between the beginning and the end of the experiment $(P<0.05)$. There were not significant differences among mineral treatments, but at the end of the experiment, the concentrations of $\mathrm{P}$ in these treatments were significantly higher than in the control $(P<0.05)$ : up to $1.1 \mathrm{mg} \mathrm{kg}^{-1}$ in mineral treatments in comparison with $0.7 \mathrm{mg} \mathrm{kg}^{-1}$ in the control. However, P contents were still low after the fertilization probably due to the clay texture of this soil, the limited increase in organic matter content, and the relatively small amount of $\mathrm{P}$ added with the fertilizer application, considering that coffee systems do not have as high $\mathrm{P}$ demands as for $\mathrm{N}$ (Iñiguez 1996). Similar to our results, Makeschin et al. (2008) also reported low levels of available $\mathrm{P}$ due to the total depletion of nutrients by the original vegetation in the same study area, which was initially occupied by forests, later by grasslands, and currently dedicated to coffee production. SadeghianKhalajabadi et al. (2006) indicated that high organic matter in soil implies high $\mathrm{N}$ and $\mathrm{P}$ contents, which did not happen in our study. We also found significant and positive correlations between organic matter and $\mathrm{P}$ contents $(r=0.88, P<0.01$, $n=12$ ).

The $\mathrm{K}$ content also significantly increased in the mineral fertilization treatments during the experiment, especially at medium and high rates $(P<0.05)$. The applied doses of mineral fertilizers proportionally increased $\mathrm{K}$ levels in the soil and all of these treatments showed significantly higher K concentrations than the control at the end of the experiment $(P<0.05)$. Contents of $\mathrm{K}$ were at optimal levels at the beginning of the experiment, probably due to the soil parent material (feldspar) and the clay texture of this soil, which has a great capacity for $\mathrm{K}$ retention. However, $\mathrm{K}$ contents exhibited a limited increase after the fertilizers application, similarly to $\mathrm{N}$ and $\mathrm{P}$ contents.

\subsection{Nitrous oxide emissions from coffee fertilization}

Figure $2 \mathrm{a}$ shows the monthly $\mathrm{N}_{2} \mathrm{O}$ fluxes from the soil in coffee systems during the experiment. Emissions slightly increased in the medium and high fertilization treatments after the first fertilizer application (January 2011). After the second fertilization (June 2011), emissions from medium and high fertilization increased again and with higher rates than those from the first fertilization, whereas the low fertilization treatment and the control experienced no changes. Emissions following the third fertilization (January 2012) were greater than the previous ones, especially in medium and high rates, which were considerable higher than the low and the control treatments. This last fertilization event produced higher emissions and with higher duration because of the higher doses of fertilizers applied during the second year, when this crop had greater nutrient needs. Our results are in agree with those of other authors (Hergoualc'h et al. 2008; Koehler et al. 2009), who showed that $\mathrm{N}_{2} \mathrm{O}$ emissions are mainly produced within a few days after the addition of mineral fertilizers.

The mineral treatments with the highest rates of fertilizers (medium and high rates) were the ones that produced the highest $\mathrm{N}_{2} \mathrm{O}$ fluxes during the experiment. Other authors (Hergoualc'h et al. 2008; Noponen et al. 2012) also observed that an excess of $\mathrm{N}$ added with mineral fertilization at great doses in coffee systems has a great contribution to increasing $\mathrm{N}_{2} \mathrm{O}$ emissions. Rochette et al. (2004) indicated that high $\mathrm{N}_{2} \mathrm{O}$ emissions from soils are due to nitrification and denitrification 
Fig. 2 a Nitrous oxide fluxes and b average annual nitrous oxide emissions during the 2-year field experiment with coffee in the different treatments (control, low, medium, and high fertilization rates). Values represent the mean of three replicates. Error bars represent standard deviations. Vertical arrows represent fertilization events. Values with the same letter are not significantly different among treatments $(P<0.05)$
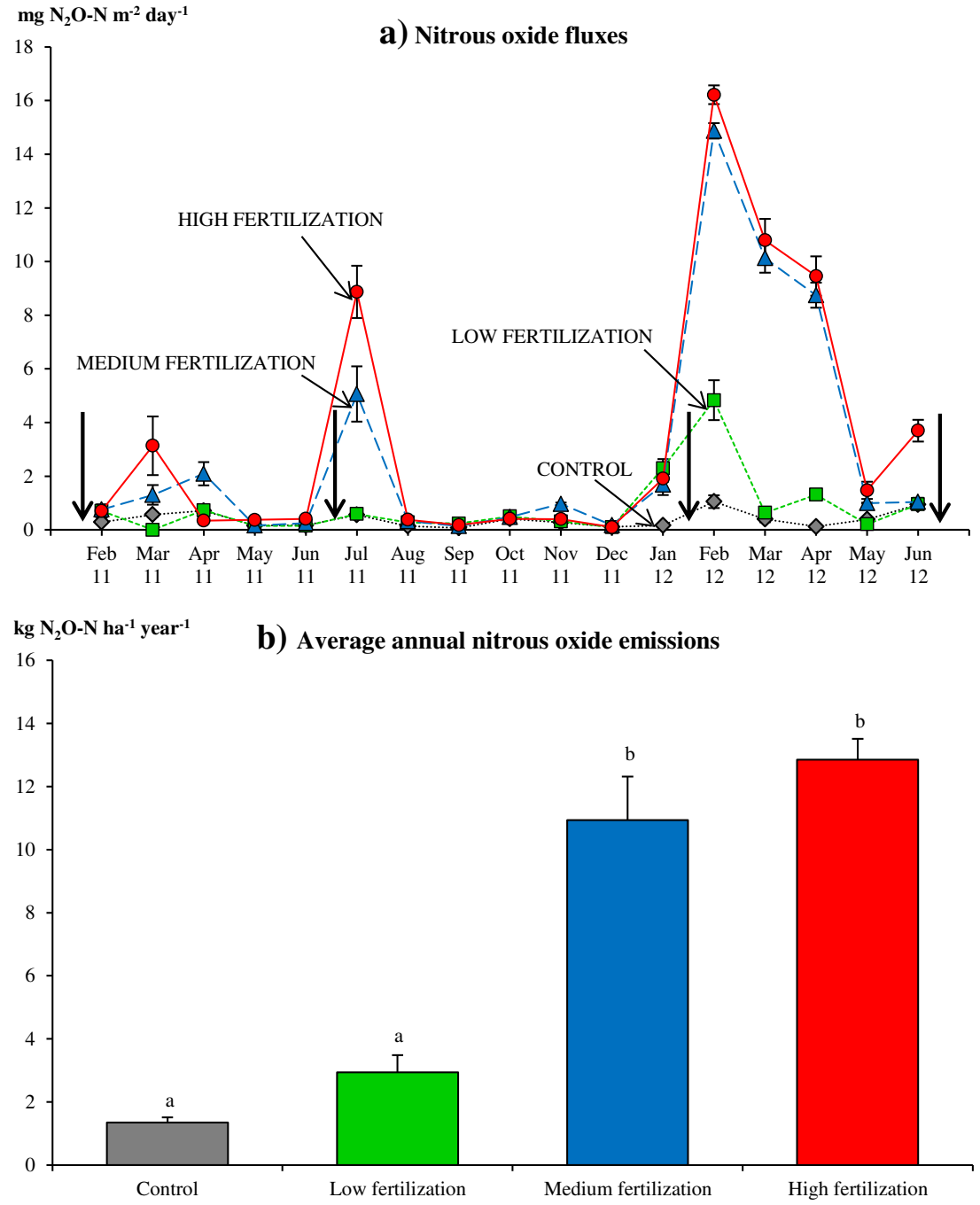

processes caused by high $\mathrm{N}$ fertilization rates in crops. The $\mathrm{N}$ content of soils was significantly and positively correlated with accumulated $\mathrm{N}_{2} \mathrm{O}$ emissions $(r=0.82, P<0.01, n=12)$.

Figure $2 \mathrm{~b}$ shows the average annual $\mathrm{N}_{2} \mathrm{O}$ emissions during the whole experiment, expressed as $\mathrm{kg} \mathrm{N}^{-1}$ year $^{-1}$. Emissions from the medium (10.9 $\mathrm{kg} \mathrm{N}_{2} \mathrm{O}-\mathrm{N} \mathrm{ha}^{-1}$ year $\left.^{-1}\right)$ and high (12.8 $\mathrm{kg} \mathrm{N}_{2} \mathrm{O}-\mathrm{N} \mathrm{ha}^{-1}$ year $^{-1}$ ) fertilization treatments were significantly higher than the others $(P<0.05)$. However, the low fertilization treatment $\left(2.9 \mathrm{~kg} \mathrm{~N}_{2} \mathrm{O}-\mathrm{N} \mathrm{ha}{ }^{-1}\right.$ year $\left.^{-1}\right)$ was not significantly different from the control one (1.3 $\mathrm{kg} \mathrm{N}_{2} \mathrm{O}-\mathrm{N}$ ha $^{-1}$ year $^{-1}$ ). The low fertilization treatment exhibited low $\mathrm{N}_{2} \mathrm{O}$ emissions, and therefore lower environmental costs than the other treatments due to the lower doses of mineral fertilizers added. Noponen et al. (2012) compared several coffee management systems, showing that the conventional moderate system, which was similar to the low fertilization treatment used in our study, resulted as one of the minor contributors to $\mathrm{N}_{2} \mathrm{O}$ emissions. Verchot et al. (2006) found $\mathrm{N}_{2} \mathrm{O}$ emissions of approximately $7 \mathrm{~kg} \mathrm{~N}^{-1}$ year $^{-1}$ in 3-year-old coffee plantations fertilized with $100 \mathrm{~kg} \mathrm{~N} \mathrm{ha}^{-1}$ year $^{-1}$ in southern Sumatra, whereas Hergoualc'h et al. (2008) reported $4.3 \mathrm{~kg} \mathrm{~N} \mathrm{ha}^{-1}$ year $^{-1}$ in monoculture coffee systems in Costa Rica fertilized with $250 \mathrm{~kg} \mathrm{~N} \mathrm{ha}^{-1}$ year $^{-1}$.

It should be taken into consideration that $\mathrm{N}_{2} \mathrm{O}$ emissions are not only induced by the fertilization. Other environmental and agricultural factors should be also determined, such as the availability of native mineral nutrients in soil, soil temperature, soil water content, tillage management, and climatic conditions (Hergoualc'h et al. 2008; Skiba et al. 1997).

\subsection{Coffee productivity}

Figure 3 shows the coffee production expressed as $\mathrm{kg} \mathrm{ha}^{-1}$ per year of green coffee during the 2-year experiment.

In both years of the experiment, yields were highest in the medium and high fertilization treatments. There were not significant differences between these two treatments, but both were significantly higher than the low fertilization treatment 
Fig. 3 Coffee production in the different treatments (control, low, medium, and high fertilization rates). Columns represent the mean of three replicates. Error bars represent standard deviations. Values with the same letter are not significantly different among treatments within the same year $(P<0.05)$

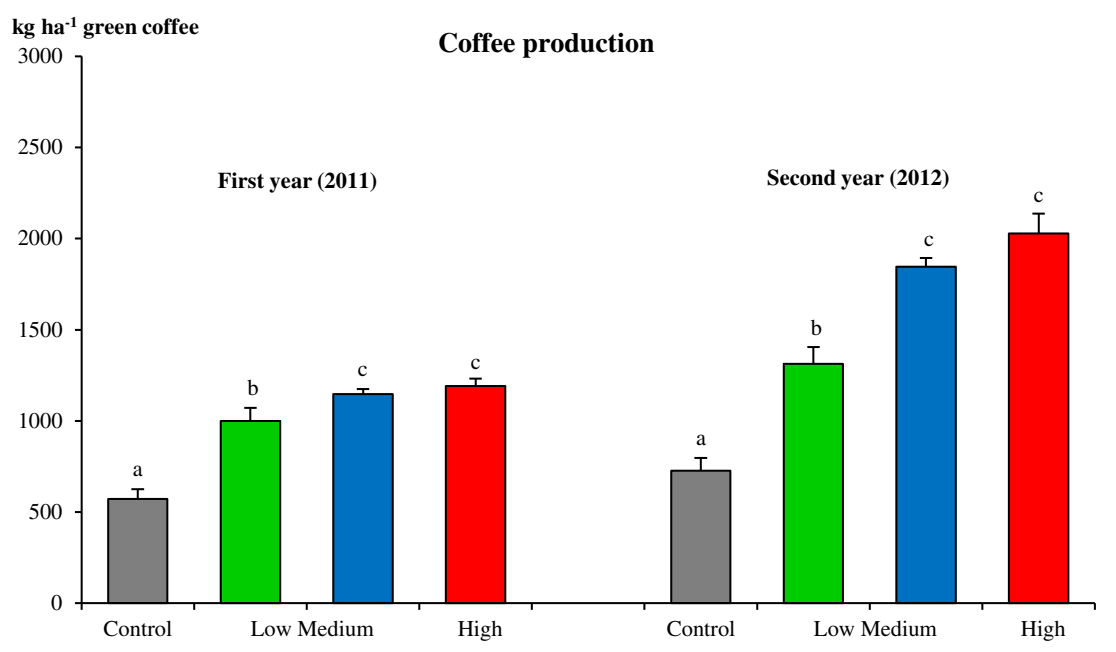

$(P<0.05)$. Nevertheless, this low fertilization rate resulted significantly higher than the control $(P<0.05)$.

The second year (2012) showed higher yields than the first one (2011), mainly due to the constant addition of fertilizers during the 2 years of the experiment and the greater age of the plants.

Either the treatments with mineral fertilization (1310 $2030 \mathrm{~kg} \mathrm{ha}^{-1}$ in 2012) or the unfertilized plots $\left(730 \mathrm{~kg} \mathrm{ha}^{-1}\right.$ in 2012) of this monoculture coffee plantations had yields considerably higher than traditional shaded coffee systems that are common in the Loja region (Ecuador), with average yields of $196 \mathrm{~kg} \mathrm{ha}^{-1}$ year $^{-1}$ (COFENAC 2011). This is in agreement with the results of Lyngbæk et al. (2001), Noponen et al. (2012), and van Rikxoort et al. (2014), who also reported yields of $1400-2400 \mathrm{~kg} \mathrm{ha}^{-1}$ of green coffee in unshaded farms versus $960-1320 \mathrm{~kg} \mathrm{ha}^{-1}$ in shaded ones.

The higher yields of our study in comparison with shaded and non-conventional systems could be due to the greater plant density and the relatively high rates of mineral fertilization. Although N, P, and $\mathrm{K}$ in soil did not increase to a great extent with the mineral fertilizers, their addition improved plant growth and evinced high significant positive relationship between coffee production in 2012 and the $\mathrm{N}$ content in soil $(r=0.94, P<0.01, n=12)$. Besides this, coffee production was also positively correlated with $\mathrm{P}(r=0.85, P<0.01, n=12)$ and K contents $(r=0.94, P<0.01, n=12)$.

It is important to mention that coffee yields of our study could increase in the following years after the experiment, when plants reach their full development.

\subsection{Coffee profitability}

Net income across the 2 years of the experiment was highest $(P<0.05)$ in the medium and high fertilization treatments, with 10,187 , and 10,584 USD ha ${ }^{-1}$, respectively (Table 2 ). Nevertheless, the low fertilization treatment (7606 USD ha ${ }^{-1}$ ) achieved significantly higher net income $(P<0.05)$ than the control one (3524 USD ha ${ }^{-1}$ ), which indicates a more optimal profitability for coffee growers at low mineral fertilization rates in comparison with unfertilized systems.

The great profits achieved in this study were due to the high prices established in 2011 and 2012 in the coffee market, which were 6.01 and 4.13 USD per kg of green coffee, respectively (ICO 2014). During the previous decade, prices were lower and very variable, which caused the abandonment of many coffee plantations. Haggar et al. (2013) reported that coffee growers of Guatemala were negatively affected by the constant changes in prices, especially from 2000 to 2004 , forcing coffee growers into other agricultural crops such as sugarcane. This led to environmental problems because of the greater generation of greenhouse gases due to changes in the use of machinery, crops, fertilization needs, etc.

Sustainability of these coffee systems must be estimated not only from productivity and profitability criteria but also from other environmental criterion, such as the production to $\mathrm{N}_{2} \mathrm{O}$ emissions ratio (Table 2). Despite that the medium and high fertilization treatments showed the highest net income, they had significantly lower $(P<0.05)$ production to $\mathrm{N}_{2} \mathrm{O}$

Table 2 Gross income, costs, net income, and production to nitrous oxide emissions ratio of coffee production in the different treatments (control, low, medium, and high fertilization rates) across the 2 years of the field experiment (2011 and 2012)

\begin{tabular}{lllll}
\hline Treatment & $\begin{array}{l}\text { Gross } \\
\text { income } \\
\left(\mathrm{USD} \mathrm{ha}^{-1}\right)\end{array}$ & $\begin{array}{l}\text { Costs } \\
\left(\mathrm{USD} \mathrm{ha}^{-1}\right)\end{array}$ & $\begin{array}{l}\text { Net income } \\
\left(\mathrm{USD} \mathrm{ha}^{-1}\right)\end{array}$ & $\begin{array}{l}\text { Production- } \\
\text { emission ratio }\end{array}$ \\
\hline Control & 6433 & 2909 & $3524 \mathrm{a} \pm 571$ & $731 \mathrm{~b} \pm 114$ \\
Low & 11,430 & 3824 & $7606 \mathrm{~b} \pm 357$ & $603 \mathrm{~b} \pm 106$ \\
Medium & 14,517 & 4331 & $10,187 \mathrm{c} \pm 123$ & $208 \mathrm{a} \pm 26$ \\
High & 15,526 & 4942 & $10,584 \mathrm{c} \pm 661$ & $188 \mathrm{a} \pm 11$ \\
\hline
\end{tabular}

Mean \pm standard deviation, $n=3$. Values followed by the same lowercase letter within the same period of the experiment are not significantly different among treatments $(P<0.05)$ 
emission ratios (208 and 188, respectively) than the low fertilization and control treatments (603 and 731, respectively). According to van Rikxoort et al. (2014), these ratios indicate an inefficient use of fertilizers at medium and high rates, where fertilizers were wasted while other growth factors, such as light, water, or the age and state of the coffee plants, were limiting coffee yields. The production to $\mathrm{N}_{2} \mathrm{O}$ emissions ratio in the low fertilization treatment was not significantly different from the ratio of the control treatment.

The medium and high fertilization treatments achieved the highest organic matter and nutrient contents in soil (Table 1), as well as the highest coffee yields (Fig. 3) and income (Table 2). However, these treatments also induced the highest $\mathrm{N}_{2} \mathrm{O}$ emissions to the atmosphere (Fig. 2b). Although the low fertilization treatment achieved lower yields and net income than the medium and high fertilization treatments, it also improved soil fertility and had a higher production-to-emission ratio, which was similar to the unfertilized treatment. Noponen et al. (2012) also reported that treatments with small amounts of inputs achieve a lower productivity and therefore a lesser profitability for coffee growers, but also induce lower environmental contamination.

\section{Conclusion}

Mineral fertilization affected soil chemical properties, especially at high fertilization rates. The fertilization of coffee plots slightly decreased soil $\mathrm{pH}$ and increased organic matter and nutrient contents. Mineral fertilization also effectively enhanced plant growth and therefore coffee production and profitability. However, fertilization also increased $\mathrm{N}_{2} \mathrm{O}$ fluxes to the environment, especially immediately after the fertilizers addition.

High and medium fertilization rates (over $150 \mathrm{~kg} \mathrm{~N}, 44 \mathrm{~kg}$ $\mathrm{P}$, and $62 \mathrm{~kg} \mathrm{~K} \mathrm{ha}^{-1}$ during the first year; $300 \mathrm{~kg} \mathrm{~N}, 87 \mathrm{~kg} \mathrm{P}$, and $125 \mathrm{~kg} \mathrm{~K} \mathrm{ha}^{-1}$ in the second year), such as those recommended on technical literature and typically used in Ecuadorian coffee plantations, achieved high yields and income but also produced high $\mathrm{N}_{2} \mathrm{O}$ emissions.

Conversely, low fertilization rates (about $70 \mathrm{~kg} \mathrm{~N}, 22 \mathrm{~kg} \mathrm{P}$, and $31 \mathrm{~kg} \mathrm{~K} \mathrm{ha}^{-1}$ in the first year; $200 \mathrm{~kg} \mathrm{~N}, 65 \mathrm{~kg} \mathrm{P}$, and $62 \mathrm{~kg} \mathrm{~K} \mathrm{ha}^{-1}$ year $^{-1}$ in the second year) resulted in considerably less harm at the same time as achieving higher yields and net income than those of unfertilized systems. The application of half the mineral fertilization rates usually recommended for coffee growers in Ecuador may be optimal for a sustainable management of monoculture coffee plantations.

Acknowledgments The authors are grateful to María Cristina Briceño, Joe Galarza, and Kléver Hernández for their assistance on sampling and laboratory analyses, to Anke Muller from the German Research Foundation for her assistance on gas chromatography analyses, and to Gonzalo
Eguiguren for providing the lands required for the field experiments. This work was co-funded and supported by the Particular Technical University of Loja and the Ministry of Higher Education, Science, Technology and Innovation of Ecuador.

\section{References}

Basavaraju TB, Gururaja Rao MR (2000) Tree - crop interactions in agroforestry systems; a brief review. Indian Forester 126:1155-1164

Borbor-Cordova MJ, Boyer EW, McDowell WH, Hall CA (2006) Nitrogen and phosphorus budgets for a tropical watershed impacted by agricultural land use: Guayas, Ecuador. Biogeochemistry 79: 135-161. doi:10.1007/s10533-006-9009-7

Bremner JM, Mulvaney CS (1982) Nitrogen-total. In: Page AL et al. (eds) Methods of soil analysis, part 2, 2nd edn. Agron Monogr 9. ASA and SSSA, Madison, WI, pp 595-624

Castro-Tanzi S, Dietsch T, Urena N, Vindas L, Chandler M (2012) Analysis of management and site factors to improve the sustainability of smallholder coffee production in Tarrazú, Costa Rica. Agric Ecosyst Environ 155:172-181. doi:10.1016/j.agee.2012.04.013

COFENAC (2011) Informe técnico 2010. Consejo Cafetalero Nacional (COFENAC), Portoviejo, Ecuador. http://www.cofenac.org/wpcontent/uploads/2010/09/Informe DT-2010 COFENAC.pdf. Accessed 14 Dec 2014

De Beenhouwer M, Muleta D, Peeters B, Van Geel M, Lievens B, Honnay O (2015) DNA pyrosequencing evidence for large diversity differences between natural and managed coffee mycorrhizal fungal communities. Agron Sustain Dev 35:241-249. doi:10.1007/s13593014-0231-8

FAO (2002) World agriculture: towards 2015/2030. Food and Agriculture Organization of the United Nations (FAO), Economic and Social Development Department, Rome, Italy. http://www.fao.org/docrep/ 004/y3557e/y3557e00.htm. Accessed 14 Dec 2014

Gee GW, Or D (2002) Particle-size analysis. In: Dane JH, Clarke Topp G (eds) Methods of soil analysis, part 4, physical methods. SSSA, Madison, pp 255-294

GEO Loja (2007) Perspectivas del medio ambiente urbano. United Nations Environment Programme (UNEP), Regional Office for Latin America and the Caribbean, Loja Municipality and Nature and Culture International. http://www.pnuma.org/deat1/pdf/ 2008GEOLoja.pdf. Accessed 14 Dec 2014

Haggar J, Medina B, Aguilar RM, Munoz C (2013) Land use change on coffee farms in southern Guatemala and its environmental consequences. Environ Manag 51:811-823. doi:10.1007/s00267-0130019-7

Hergoualc'h K, Skiba U, Harmand JM, Hénault C (2008) Fluxes of greenhouse gases from Andosols under coffee in monoculture or shaded by Inga densiflora in Costa Rica. Biogeochemistry 89: 329-345. doi:10.1007/s10533-008-9222-7

ICO (2014) Indicator prices: annual and monthly averages. International Coffee Organization (ICO), London, United Kingdom. http://www. ico.org/prices/p2.htm. Accessed 14 Dec 2014

Iñiguez M (1996) Fertilidad y fertilización del suelo. Universidad Técnica de Machala, Machala

Koehler B, Corre MD, Veldkamp E, Wullaert H, Wright SJ (2009) Immediate and long-term nitrogen oxide emissions from tropical forest soils exposed to elevated nitrogen input. Glob Chang Biol 15:2049-2066. doi:10.1111/j.1365-2486.2008.01826.x

Loftfield N, Flessa H, Augustin J, Beese F (1997) Automated gas chromatographic system for rapid analysis of the atmospheric trace gases methane, carbon dioxide, and nitrous oxide. J Environ Qual 26:560 564. doi:10.2134/jeq1997.00472425002600020030x 
Lyngbæk AE, Muschler RG, Sinclair FL (2001) Productivity and profitability of multistrata organic versus conventional coffee farms in Costa Rica. Agrofor Syst 53:205-213. doi:10.1023/ A: 1013332722014

Makeschin F, Haubrich F, Abiy M, Burneo JI, Klinger T (2008) Pasture management and natural soil regeneration. In: Beck $\mathrm{E}$ et al (eds) Gradients in a tropical mountain ecosystem of Ecuador. Ecological Studies 198. Springer, Berlin, pp 397-408

Mosier AR, Duxbury JM, Freney JR, Heinemeyer O, Minami K (1996) Nitrous oxide emissions from agricultural fields: assessment, measurement and mitigation. Plant Soil 181:95-108. doi:10.1007/97894-011-5450-5 97

Murphy J, Riley JP (1962) A modified single solution method for the determination of phosphate in natural waters. Anal Chim Acta 27: 31-36. doi:10.1016/S0003-2670(00)88444-5

Nelson DW, Sommers LE (1996) Total carbon, organic carbon and organic matter. In: Sparks DL (ed) Methods of soil analysis, part 3, chemical methods. SSSA, Madison, pp 961-1010

Noponen MRA, Edwards-Jones G, Haggar JP, Soto G, Attarzadeh N, Healey JR (2012) Greenhouse gas emissions in coffee grown with differing input levels under conventional and organic management. Agric Ecosyst Environ 151:6-15. doi:10.1016/j.agee.2012.01.019

PROCAFE (1995) Interpretación de resultados de análisis de suelo y recomendaciones de fuentes orgánicas e inorgánicas para el cultivo del café. Fundación Salvadoreña para Investigaciones del Café (PROCAFE), Santa Tecla, El Salvador

Rochette P, Angers DA, Bélanger G, Chantigny MH, Prévost D, Lévesque $\mathrm{G}$ (2004) Emissions of $\mathrm{N}_{2} \mathrm{O}$ from alfalfa and soybean crops in eastern Canada. Soil Sci Soc Am J 68:493-506. doi:10. 2136/sssaj2004.4930

Romero-Alvarado Y, Soto-Pinto L, García-Barrios L, Barrera-Gaytán JF (2002) Coffee yields and soil nutrients under the shades of Inga sp. vs. multiple species in Chiapas, Mexico. Agrofor Syst 54:215-224. doi:10.1023/A:1016013730154

Rondón MA (2000) Land use change and balances of greenhouse gases in Colombian tropical savannas. Dissertation, Cornell University, Ithaca, NY

Sadeghian-Khalajabadi S, Garcia López JC, Montoya Restrepo EC (2006) Respuesta del cultivo de café a la fertilización con N, P, K y $\mathrm{Mg}$ en dos fincas del departamento del Quindío. Cenicafé 57:58 69

Sierra R (1999) Propuesta preliminar de un sistema de clasificación de vegetación para el Ecuador continental. Project INEFAN/GEFBIRF and EcoCiencia, Quito, Ecuador

Skiba U, Fowler D, Smith KA (1997) Nitric oxide emissions from agricultural soils in temperate and tropical climates: sources, controls and mitigation options. Nutr Cycl Agroecosyst 48:139-153. doi:10. 1023/A:1009734514983

Suarez DL (1996) Beryllium, magnesium, calcium, strontium. In: Sparks DL (ed) Methods of soil analysis, part 3, chemical methods. SSSA, Madison, pp 575-601

Tully KL, Lawrence D, Scanlon TM (2012) More trees less loss: Nitrogen leaching losses decrease with increasing biomass in coffee agroforests. Agric Ecosyst Environ 161:137-144. doi:10.1016/j. agee.2012.08.002

van Rikxoort H, Schroth G, Läderach P, Rodríguez-Sánchez B (2014) Carbon footprints and carbon stocks reveal climate-friendly coffee production. Agron Sustain Dev 34:887-897. doi:10.1007/s13593014-0223-8

Verchot LV, Hutabarat L, Hairiah K, van Noordwijk M (2006) Nitrogen availability and soil $\mathrm{N}_{2} \mathrm{O}$ emissions following conversion of forests to coffee in southern Sumatra. Glob Biogeochem Cycles 20, GB4008. doi:10.1029/2005GB002469 